820

6120.18

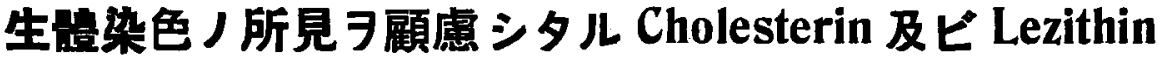 ノ口蓄扁桃腺細胞ニ及ボ ス頡頑作用二就テノ研究
}

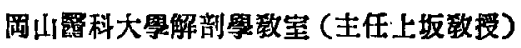

福 武 敏 重

目

第 1 章 緒言及ビ文暗

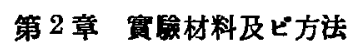

第 3 章 賽毁成縝

第 1 節 Cholesterin 7 以テセル叟驗成績

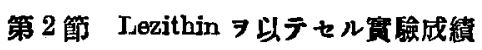

大

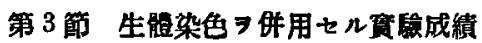
第 4 章 稳括及ビ考按 第 5 章 結 諭 文 缺 附僈說明

\section{第 1 辛 緒官及ヒ文践}

口蓋扁挑腺二關スル業績八恢ル多數ニシテ枚擧二遑ナキモ。. Cholesterin 或ハ之ト頡領的作

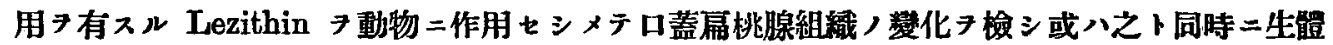
染色 7 併用シ其ノ所見 7 組織的二探求シタルモノハ余ノ知レル範園內ニテハ之ナキガ如シ。只 Cholesteatose 二於ヶル生體細胞ノ色素攝取ノ狀二就テ Anitschkow, 中院等ノ确究アルノi。

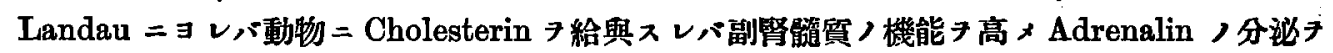

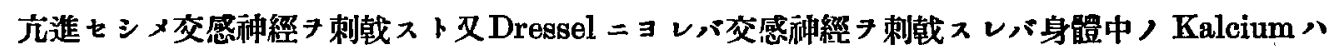

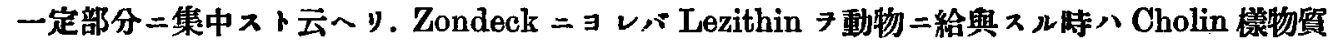
形成セラレ副交感神經フ刺戟スルナラント然レドモ之等ノ問題フ組織學的方面ヨリ探求セシモ

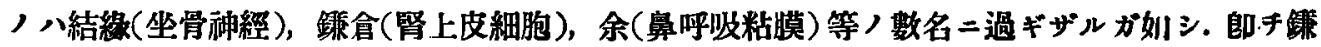

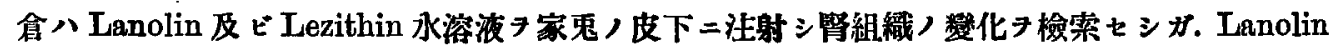

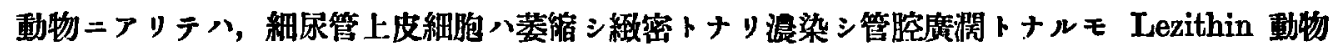

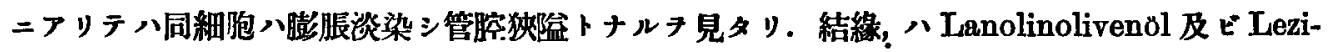

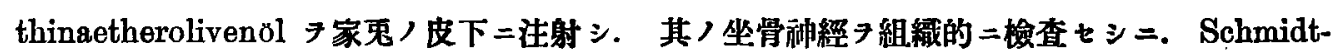
Lantermann 氏制八膨脤性ハLanolin 動物ニテハ著明トナリ. Lezithin 動物ニテハ幽微トナル

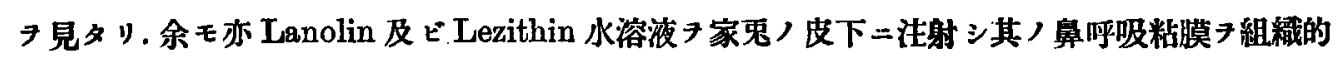

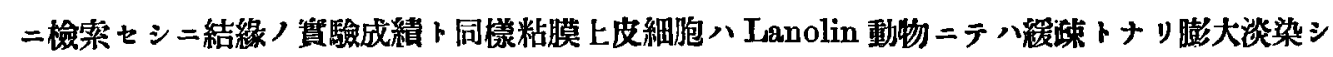

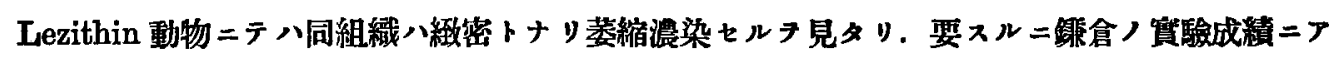

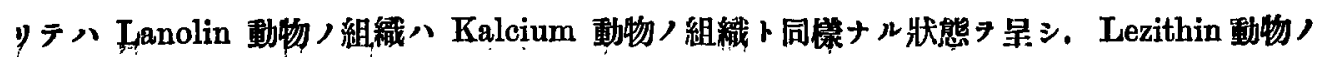


組織ハKalium 動物ノモノト同樣ナル所見タ示セル二反シ。結缘及ビ余，實驗成續ニアリテハ

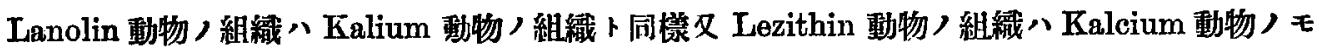

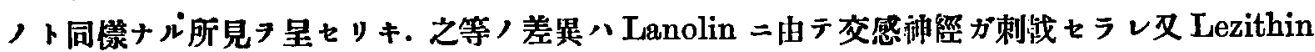
二由テ副交感神經ガ刺戙サルル結果トシテ，身體中ノ Kalcium 或ハ Kalium カ Dressel 等方臆 想セルガ如ク一定部二集中スル二起因スルモノナルガ如シ．然ラバ蓋扁恌腺組絨が之等兩物

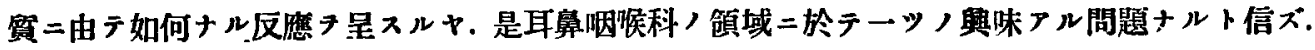
体テ余ハ本問題，研究二從事シ同時二生體染色，狀二注意七り。蓋シ生體染色ガ陽性ナルト否

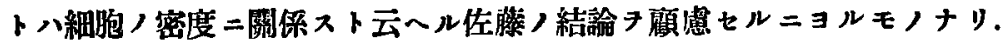

\section{第 2 章賽驗材料及ヒ方法}

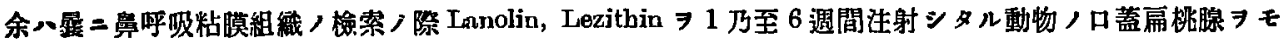

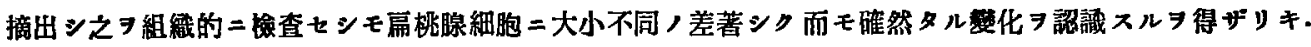

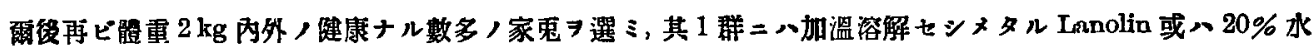

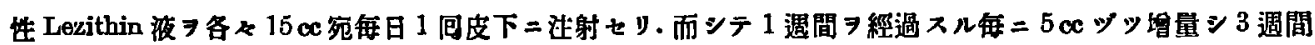

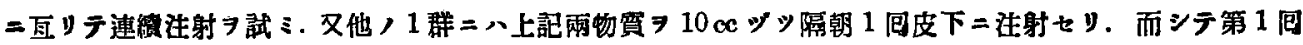

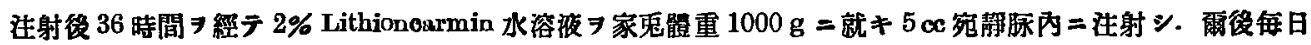

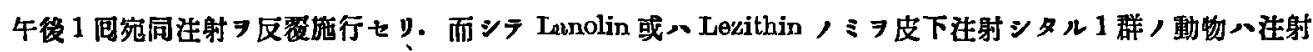

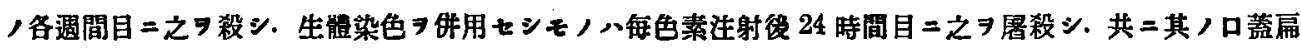

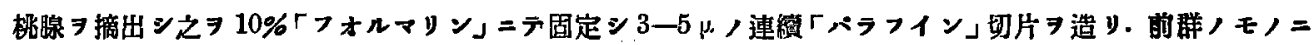

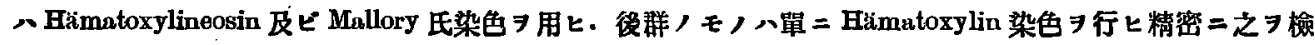
查セり.

\section{苐3 章 宽 驗 成 綪}

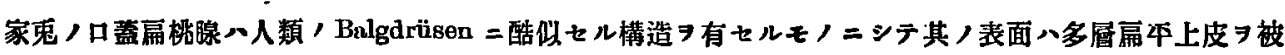

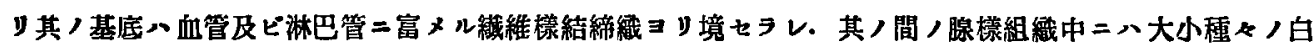

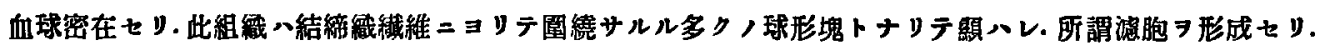

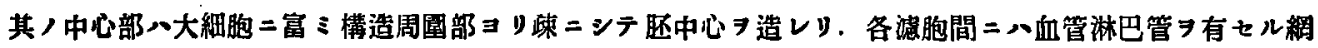

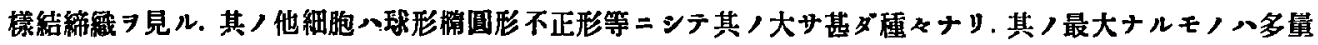

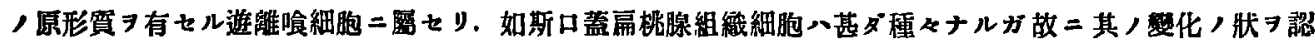

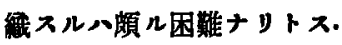

\section{第 1 節 Lanolin $ヨ$ 以テセル實驗成績}

第 1 項 1 週間往射七シモノ/所見

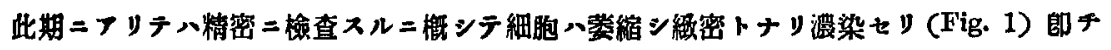




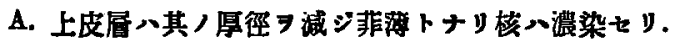

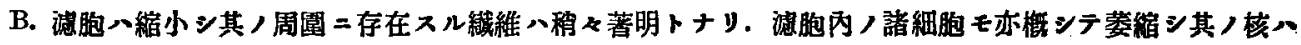

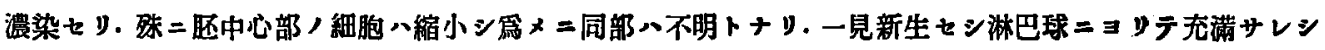
カノ如キ狀 $尹$ 呈セリ。

第 2 項 2 週䦎注射七シモノノ所見

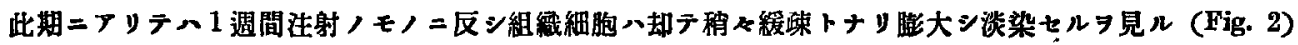
即子

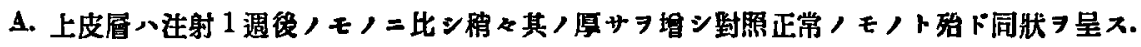

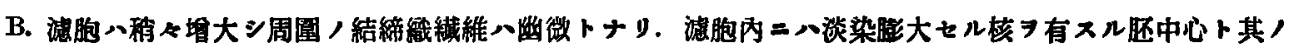
周堛二密在セ几淋巴球群トシ明カ二區刷シ得ルニ至ル。

第 3 項 3 週間注射七シモノ/所見

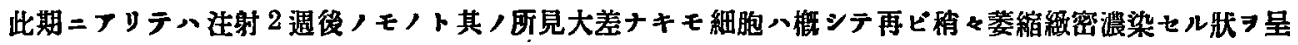
ス (Fig. 3) 即千

A. 上皮居へ再ビ梢を其/厚徑ヨ減シ核へ漫染セリ。

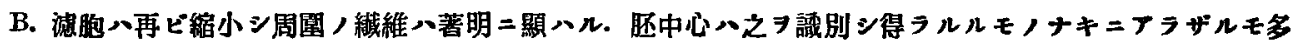

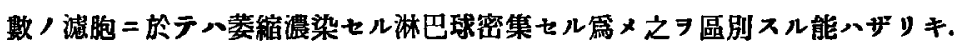

\section{第 2 節 Lezithin $\exists$ 以テセル實驗成績}

第 1 項 1 週間注射七シモノ/所見

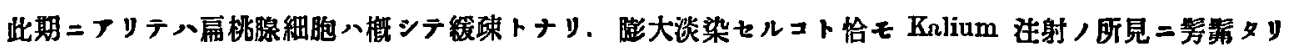
(Fig. 4) 即千

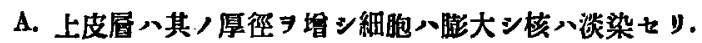

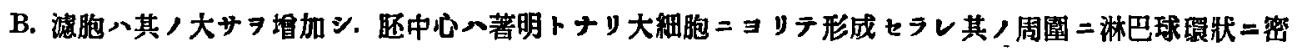

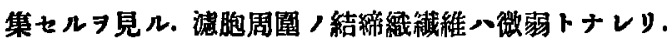

第 2 項 2 週間注射七シモノノ所見

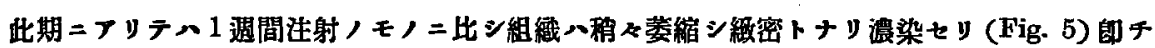
A. 上皮層心殆ド正常對照ノモハト均シキ厚徑ヨ有スレドモ核八漫染セリ.

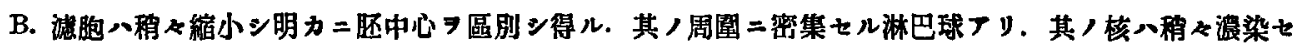
リ・減胞周園 ノ䋐維モ亦著明トナレリ.

\section{第 3 項 3 週間注射七シモノ，所見}

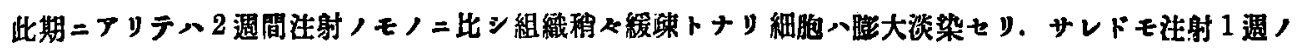
モノニ比シテ遥二其，度微弱ナリ (Fig. 6)郎チ

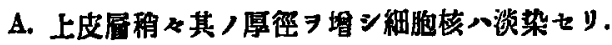




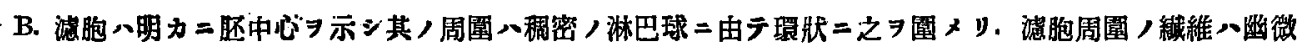
トナレリ.

第 3 節 生能染色 $\exists$ 併用セル實驗成續

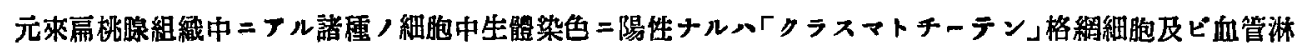
巴管/內皮細胞其ノ他之等細胞ヨリ分離セル組紻球ナリトス.

第 1 項 Lanolin 動物二生體染色F施セシモノノ所見

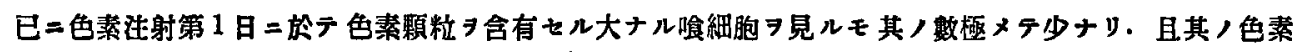

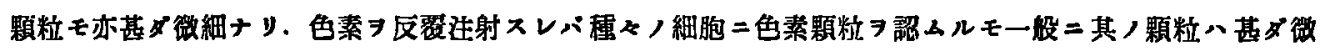
細ナリトス (Fig. 7).

第 2 項 Lezithin 動物二生體染色 施七シモノノ所見

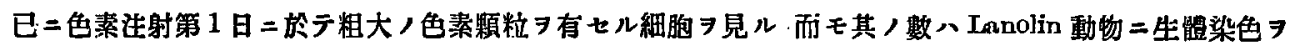

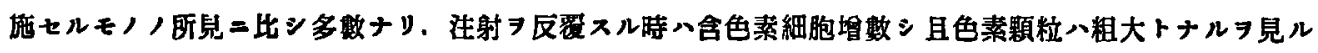
(Fig. 8).

\section{第 4 草總括及ヒ考按}

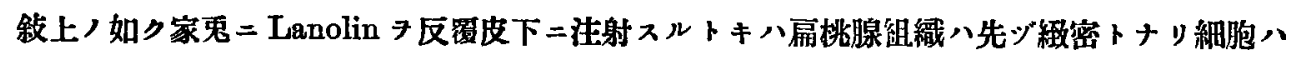
概シテ萎縮シ濃染スルキ見ル。然レドモ 2 週間二互り注射フ反灌スルトキハ却ッテ扁桃腺組

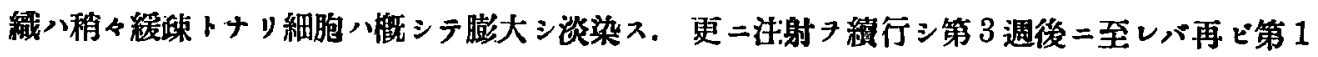

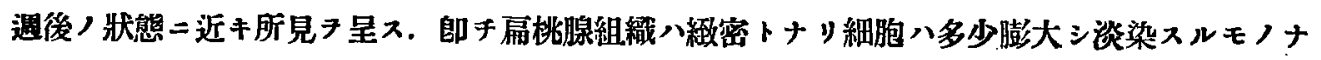

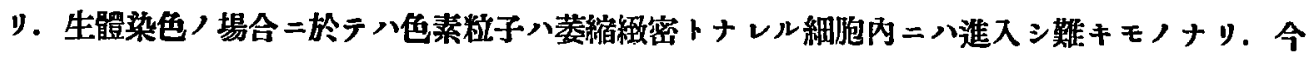
Ianolin 動物二生唭染色 7 併用スルトキ八少クモ初期二於テハ扁桃腺細胞ハ概シテ萎縮二陷レ ルガ故二色素ハ單二生體染色习試 細咆內ノ色素顆粒モ微細ノ狀ニ止リ又色素フ攝取セル細胞ノ數も少キモノトス。

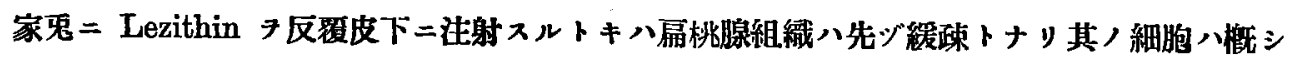

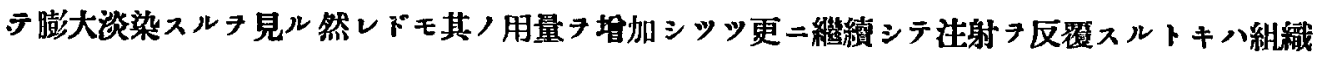

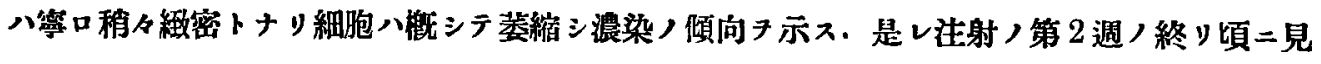

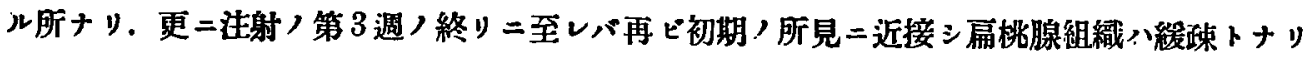

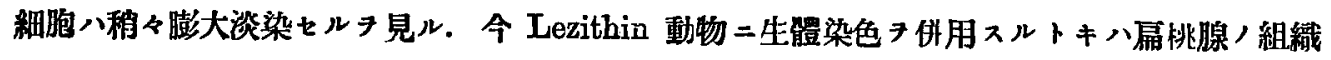

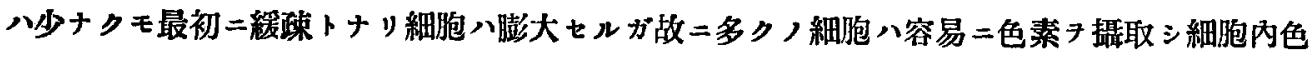
素ノ濃度ハ高マリ篇メ二粗大ノ色素顆粒ヨ含有セル細胞多り現出スルモノトス. 思フ二動物二

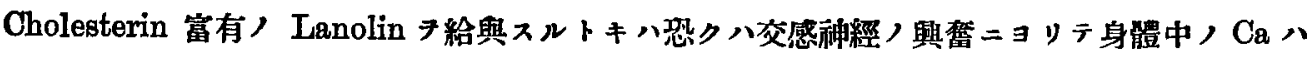

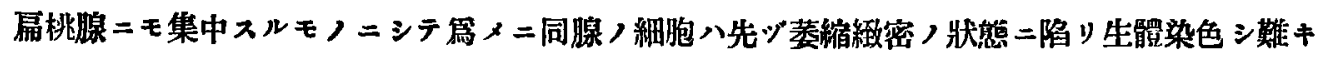




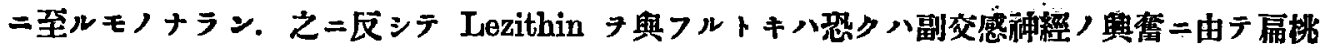

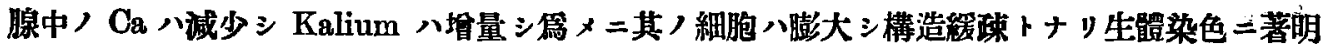

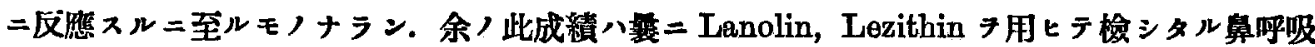

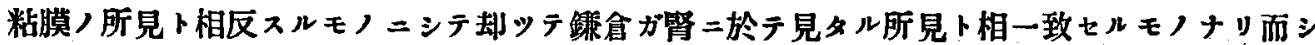

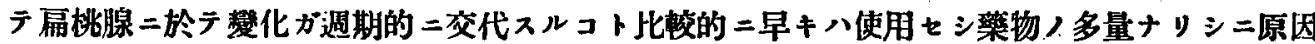
スルモノナラン.

\section{第 5 革結 論}

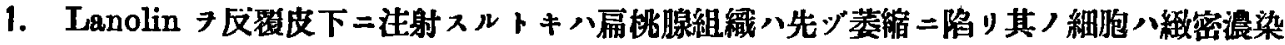

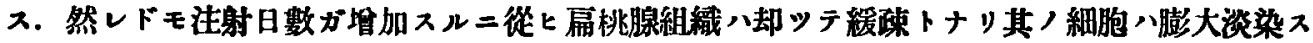

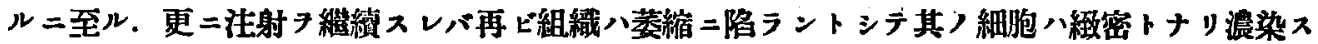
ルノ傾向タ示スモノナリ。

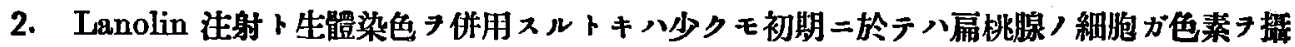
取スル能力減ズルフ見ル。

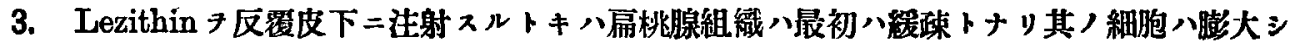

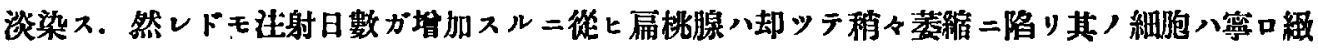

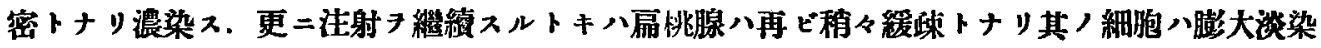
スル傾向タ示ス.

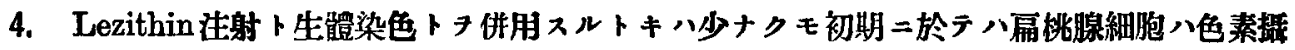
取ノ能力タ鿾スタ見ル。

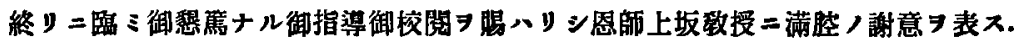

(5. 11. 5. 受解)

\section{主 要 文}

1) A. Denker und O. Kahler, Handbuch der Bnls-Nasen-Ohren-Heilkunde. 1926. 2) Stähr, Lehrbuch der Histologie. 1928. 3) S. G. Zondek, Die Elektrolyte. 1927.

4) Rudolf Hober, Physikalische Ohemie der zellen und der Gewebe. 1924. 5) Kamakura, Arbeiten aus der Medizinisohen Universität Oknyama. 1. Bd. 4. Heft. 1930. 6) Yzien, Arbeiten aus der Medizinisohen Univerisitat Oknyama. 1. Bd. 1. Heft: 1928. 7) Sato, Folin Anatomica Jnponica Bd. VIII, Heft. 1. 1929.

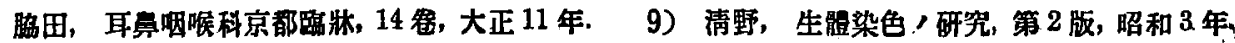




\section{程武論文附圖}

Fig. 1.

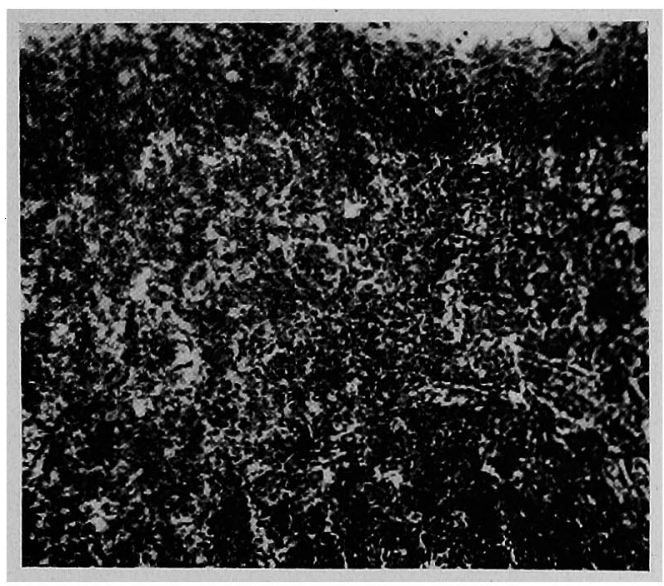

Fig. 3.

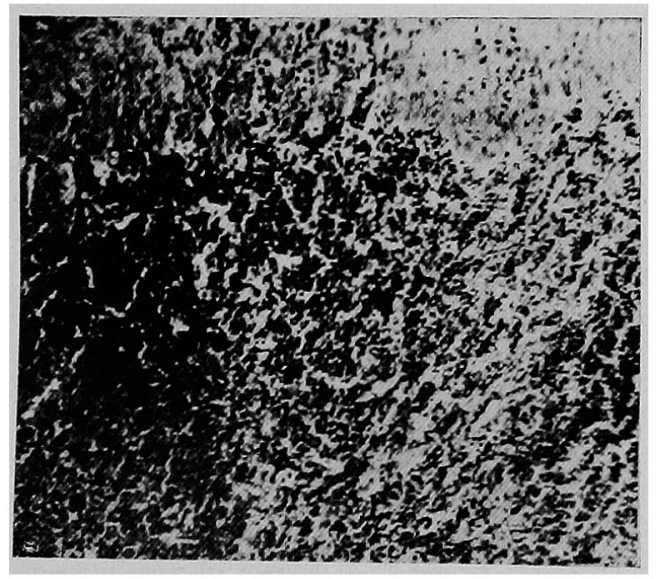

Fig. 5.

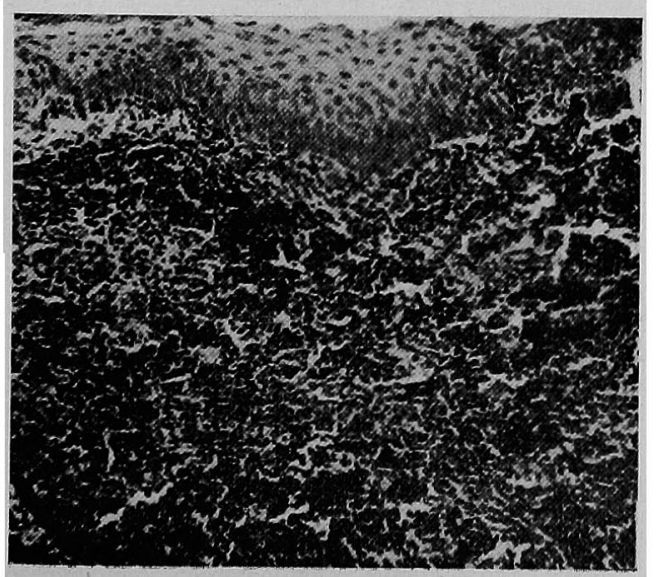

Fig. 2.

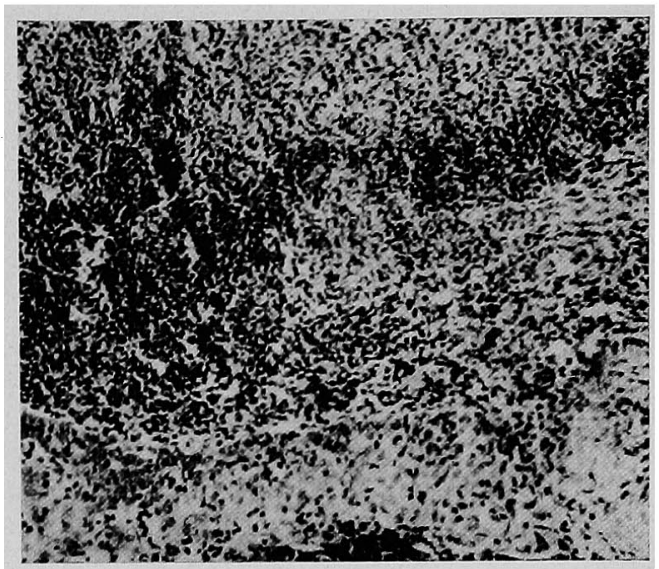

Fig. 4.

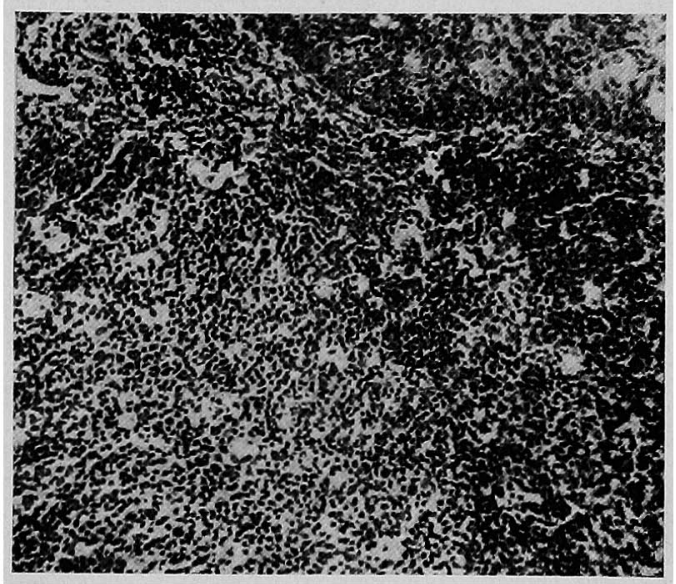

Fig. 6.

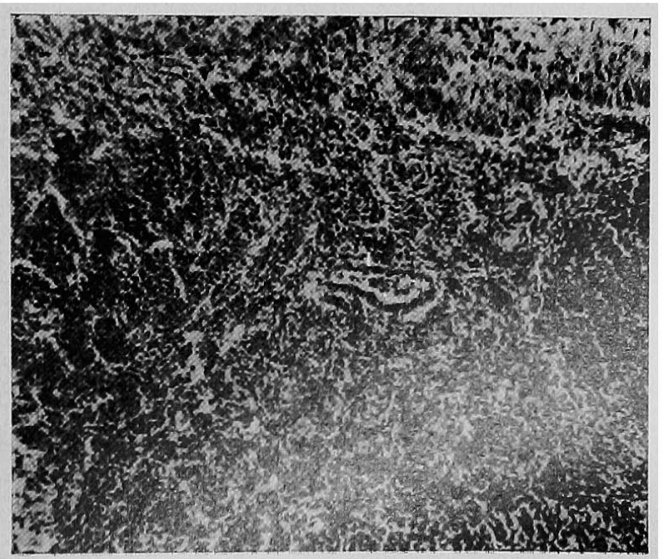




\section{福 武論文附團}

Fig. 7.

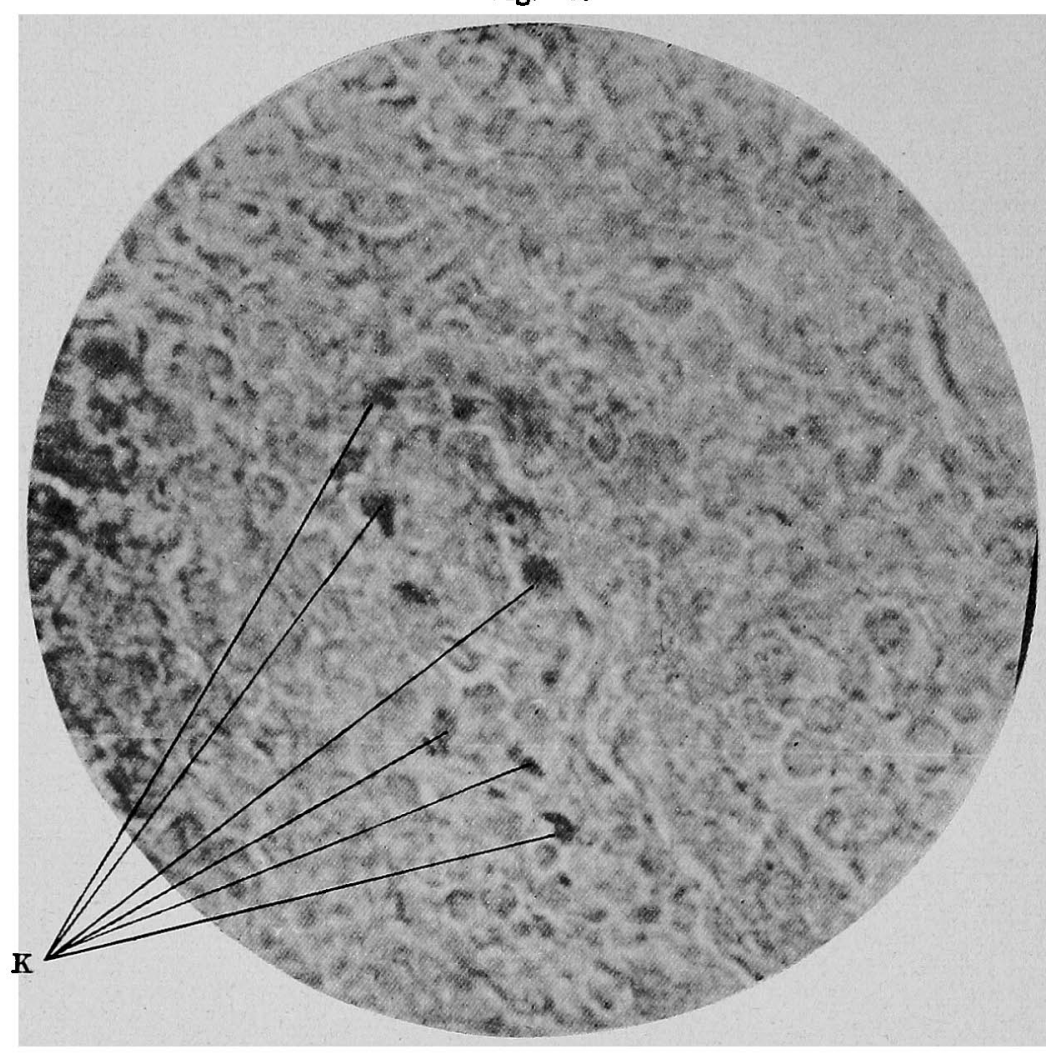

Fig. 8.

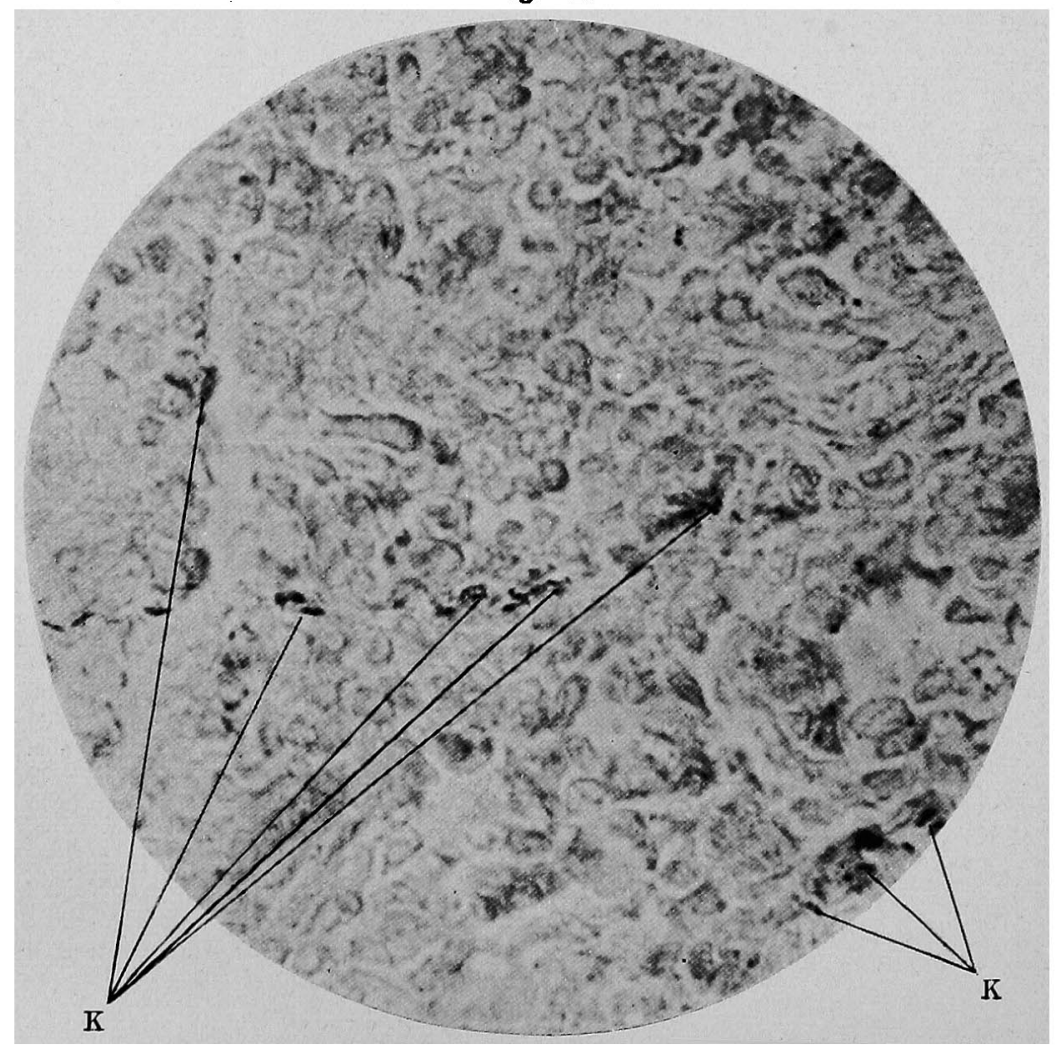




\section{Erklärung der Abbildungen.}

Fig. 1. Sohnitt der Gaumenmandel eines mit Inanolin eíne Woohe lang behandelten Kaninchens.

Fig. 2. Derselbe eines mit Tanolin 2 Wochen!ling behandelten Kanjnohens.

Fig. 3. Derselbe eines mit Lanolin 3 Wochen ling behnndelten Kaninohens.

Fig. 4, Derselbe eines mit Lezithin eine Woche ling behandelten Kaninohens.

Fig. 5. Derselbe eines mit Lezithin 2 Woohen lang behandelten Kaninchens.
Fig. 6. Derselbe eines mit Lezithin 3 Wochen lang behandelten Kaninchens.

Zeiss. $10 \times 10$ Auszug $40 \mathrm{om}$.

Fig. 7. Derselbe eines mit Lanolin und Lithionkarmin abwechselnd 5 Tinge lang behnndelten Kaninchens.

$\mathrm{K}=$ Farbstoffgranuln innerhalb der Zellen.

Fig. 8. Derselbe eines mit Lezithin und Lithiomkaimin abwechselnd 5 Tage lnng behnndelten Kaninchens.

K= Intrazelluläre Farbstoffgranula. Zeiss. $15 \times 40$ Auszulg $40 \mathrm{~cm}$. 
Kurze Inhaltsangabe.

\title{
Untersuchungen über die antagonistischen Wirkungen von Cholesterin und Lezithin auf die Zellen der Gaumenmandel mit Berücksichtigung ihrer Befunde in Bezug auf die vitale Färbung.
}

\author{
Von \\ Toshishige Fukutake. \\ Aus dem anatomischen Institute der Universirät Okayama \\ (Vorstand: Prof. K. Kösaka). \\ Eingegangen am 5. November 1930.
}

Wenn man beim Kaninchen täglich einmal durch mehrere Tage hindurch Lanolin injiziert, so wird das Mandelgewebe zuerst dichter, indem seine Zellen im allgemeinen einschrumpfen und sich intensiv färben (Fig. 1). Dieser Befund ist wahrscheinlich darauf zurückzuführen, dass der Kalziumgehalt der Mandel wegen der Sympathicuserregung zunimmt. Im Verlauf der Behandelungszeit tritt aber eine reaktionäre Erscheinung auf, wobei viele Mandelzellen etwas anschwellen und sich schwächer färben (Fig. 2), um dann wieder einer Schrumpferscheinung Platz zu machen (Fig. 3). Wenn man beim Kaninchen Lanolin und Lithionkarmin abwechselnd eine Zeit lang injiziert, so tritt die Farbstoffaufnahme der Mandel in den Hintergrund, indem die farbstoffhaltigen Zellen spärlicher und die intrazellulären Farbstoffgranula feiner sind (Fig. 7) als im Falle der einfachen Vitalfärbung.

Gerade umgekehrtes Verbalten trifft man im Falle der wiederhalten Lezithininjektionen, indem die Mandelzellen eine Zeit lang im allgemeinen anschwellen und sich schwach färben (Fig. 4), was wahrscheinlich darauf beruht, dass der Kaliumgehalt der Mandel infolge der Parasympathicuserregung zunimmt. Später kommt aber reaktionäro Schrumpferscheinung zum Vorschein (Fig. 5), um dann wieder umgekehrten Zustand zu zeigen (Fig. 6). Bei abwechselnden Injektionen von Lezithin und Lithionkarmin tritt die Farbstoffaufnahme der Mandel in erster Linie in den Vordergrund, indem die farbstoffhaltigen Zellen zahlreicher und die intrazellulären Karmingranula gröber sind (Fig. 8) als im Falle der einfachen Vitalfärbung. 